This item was submitted to Loughborough's Research Repository by the author.

Items in Figshare are protected by copyright, with all rights reserved, unless otherwise indicated.

\title{
Shaping and re-shaping social capital in buyer-supplier relationships
}

PLEASE CITE THE PUBLISHED VERSION

https://doi.org/10.1016/j.jbusres.2009.12.009

\section{PUBLISHER}

(c) Elsevier

VERSION

AM (Accepted Manuscript)

\section{PUBLISHER STATEMENT}

This work is made available according to the conditions of the Creative Commons Attribution-NonCommercialNoDerivatives 4.0 International (CC BY-NC-ND 4.0) licence. Full details of this licence are available at: https://creativecommons.org/licenses/by-nc-nd/4.0/

\section{LICENCE}

CC BY-NC-ND 4.0

\section{REPOSITORY RECORD}

Hughes, Mathew, and Robert K. Perrons. 2019. "Shaping and Re-shaping Social Capital in Buyer-supplier Relationships”. figshare. https://hdl.handle.net/2134/26368. 


\title{
Shaping and Re-shaping Social Capital in Buyer-Supplier Relationships
}

\section{JBR BB-6325 REV3}

\author{
Mathew Hughes \\ Robert K. Perrons
}

Send correspondence to Mathew Hughes, Nottingham University Business School, Jubilee Campus, Wollaton Road, Nottingham, NG8 1BB United Kingdom (e-mail: mat.hughes@nottingham.ac.uk). Robert K. Perrons, Queensland University of Technology, School of Management, GPO Box 2434, Brisbane, QLD 4001, Australia; Shell International Exploration \& Production, P.O. Box 51510, New Orleans, LA 70151-1510, USA (e-mail: perrons@alum.mit.edu). 


\begin{abstract}
Social capital plays an important role in explaining how value is created from firms’ network relationships, but little is understood about how social capital is shaped over time and how it is re-shaped when firms consolidate their network ties. In response, this study explores the evolution of social capital in buyer-supplier relationships through a case study of a company undertaking radical product innovation, and examines the corresponding changes in the firm's network of buyer-supplier relationships. The analysis shows that social capital is built in a decidedly non-linear and non-uniform manner. The study also reveals considerable interaction among the dimensions of social capital throughout the evolution of the firm's network, and emphasizes the importance of the cognitive dimension-a feature receiving little attention thus far. The evidence shows, too, that efforts to strengthen social capital need to increase when network ties are sacrificed to prevent unintended consequences for firms’ longer-term value creation.
\end{abstract}

Key-words: Buyer-supplier relationships, innovation, social capital. 


\section{Shaping and Re-shaping Social Capital in Buyer-Supplier Relationships}

\section{INTRODUCTION}

A firm's network of relationships offers privileged access to knowledge, resources, technologies, and markets that can be leveraged to create new value (Ink pen \& Tsang, 2005). However, the positive conditions necessary for the exchange of such resources is dependent on the social capital that the firm develops as its inter-firm relationships grow (Nahapiet \& Ghoshal, 1998). Social capital is essentially the sum of resources that a firm accrues by virtue of possessing a durable network of inter-firm relationships (Nahapiet \& Ghoshal, 1998). Prior investigations in the literature seek to examine empirically the benefits of social capital, but the popularity of the social capital construct may be outpacing its conceptual development (Rodan \& Galunic, 2004).

Earlier attempts to describe the theoretical underpinnings of this area propose that interactions along structural, relational, and cognitive dimensions nurture social capital, and that increases in social capital can help to unlock resources that typically improve firm performance (Nahapiet \& Ghoshal, 1998). However, the research community's eagerness to examine the benefits of social capital empirically has resulted in an oversimplification of the complexity of managing inter-firm ties over time. Two problems emerge from this oversimplification. First, different types of network ties may require different structural, relational, and cognitive conditions, and their effects on unlocking value from relationships may not be uniform (Inkpen \& Tsang, 2005). This research area would accordingly benefit from investigations addressing the issue of how social capital can be built, shaped, and deployed over time en route to determining whether exceptions exist to the linear process currently suggested in the literature. 
Second, social capital is not without risks. As a firm's network grows, ties change in their relative strength and importance and, over time, redundancy in the network of ties would be expected (McFadden \& Canella, 2004). Firms are then faced with situations where previously strong ties may become less relevant, or may need to be sacrificed altogether. The literature has so far failed to offer constructive examples of how ties can be weakened or sacrificed, or how negative changes in social capital can cause problems for a firm.

This study responds to these gaps by studying social capital in the buyer-supplier relationships of a firm undergoing a period of radical innovation. Two research questions are addressed. First, can social capital be built in a way that is different from the linear trajectory portrayed in the literature? And second, when linkages with other firms must be severed or sacrificed, how can this be done in a way that preserves social capital as much as possible? To answer these questions, this investigation puts forward an in-depth case study of an organization's buyer-supplier relationships and examines two sets of ties therein. The first set relates to its core product, while the second relates to ties formed to develop and commercialize a radical innovation that was very different from the firm's core product line. The contrast between these two scenarios sheds light on the shaping and usage of social capital, reveals some exceptions to the current theory in this area, and offers implications for both theory and practice.

\section{THEORY AND PROPOSITIONS}

Research in the area of social capital emerges from the theoretical debate between competition and collaboration. Putnam $(1995,2000)$ argues that people have become increasingly disconnected from each other such that the stock of social capital in society—-that is, the fabric of connections among people and organizations—-has declined rapidly. Social 
disconnections decrease information flow, weaken norms of reciprocity, and generate a mentality that values competition over collaboration. Putnam's observations come at a time when academic researchers increasingly extol the virtues of collaboration above competition as pathways to superior business performance (Gulati et al., 2000). Extending Putnam's views into the buyer-supplier context, this study adopts his argument that increasing connections among firms can enrich the value-creation process. Specifically, action driven by common instead of competitive interests can serve to improve conditions for all of the stakeholders involved in a firm's relationships.

\subsection{Social Capital}

Social capital represents the ability of firms to secure benefits from networks. These benefits can include access to knowledge, resources, technologies, markets, and business opportunities (Inkpen \& Tsang, 2005). Following Nahapiet \& Ghoshal (1998), social capital is the aggregate of resources embedded in, available through, and resulting from the network of relationships held by a firm. A network tie such as a supply contract between one firm and another creates a social capital resource. As interactions within the linkage between the firms increase, social capital is improved, thereby potentially increasing the flow of benefits.

Nahapiet \& Ghoshal (1998) identify structural, relational, and cognitive dimensions of social capital. The structural dimension reflects the configuration of linkages and overall pattern of connections in a set of relationships (Nahapiet \& Ghoshal, 1998). The density, connectivity, and variation in the nature (or purpose) of ties held by a firm are qualitative measures of the structural dimension. The nature of ties between firms greatly impacts the opportunities for social capital transactions, and thus the type and uniqueness of the benefits on offer (Burt, 1992). 
The relational dimension captures the amount of resources created and leveraged through ties, and the firm's reliance on these ties (Nahapiet \& Ghoshal, 1998). The level of trust and relational dependence between firms in a particular linkage are qualitative indicators of the relational dimension. One firm's reliance on another creates trust, and the extent to which a firm actively participates in relationships shapes trust further, which then influences the outcomes a firm can obtain (Hughes et al., 2007). Trust reduces the risk of opportunistic behavior and brings firms closer together to collaborate more richly (Ink pen \& Tsang, 2005).

The cognitive dimension refers to shared expectations, interpretations, and systems of meaning between firms (Nahapiet \& Ghoshal, 1998). Common standards of activity, shared expectations of behavior, and beliefs about the nature and purpose of the tie are qualitative indicators of the cognitive dimension (Galati et al., 2000). Shared expectations create rules that govern appropriate behavior and affect the nature and degree of cooperation among firms.

\subsection{The Shaping and Use of Social Capital in Buyer-Supplier Relationships}

Buyer-supplier relationships represent multi-organization social processes whereby parties interact, exchange information, and evolve new or novel relationships based on interdependencies, exchanges, and mutual problem-solving (Morris \& Holman, 1988). Effective buyer-supplier relations can create transaction cost and resource-based advantages, but the workings and outcomes of buyer-supplier dyads are governed by relational dimensions (e.g., power/dependence relationships), social-structural dimensions (e.g., close versus arms-length ties), and normative dimensions (e.g., norms, expectations, and accepted practices) (Morris \& Holman, 1988). These variables render buyer-supplier dyads subject to social capital. 
Firms tend to develop portfolios of arms-length and close-partner relationships in their buyer-supplier networks. The mix of weak and strong ties depends on the nature and complexity of the product (Cousins \& Lawson, 2007). More complex products require more information exchange, more closely aligned operations, and more inter-firm cooperation, thereby increasing the strength of these ties (Cannon \& Perreault, 1999). However, a complex product is still supplemented by weak ties with additional supplier firms for simple components. How social capital is then generated, shaped, and used throughout these relationships is likely to vary according to the frequency of interaction between the collaborating firms.

The structural dimension of social capital then interacts with the reliance of the firm on key network ties, and is therefore not independent of its relational dimension (Nahapiet \& Ghoshal, 1998). A high degree of reliance on a partner increases the incidence of cooperation, which in turn changes linkages from standard arms-length exchanges to closer strategic partnerships (Bensaou, 1999). High-involvement ties exhibit considerable mutual dependence that forms considerable social capital as a result. But low-involvement ties consist of fewer relation-specific investments, and are typically driven by price concerns than innovation (Cousins \& Lawson, 2007). As relational exchanges vary in their level of involvement, expectations of mutual interest and return can increase (Mukherji \& Francis, 2008). The social capital developing between these firms acts as a governance mechanism to ensure that these obligations are appropriately met. The subsequent trust decreases collaborating firms' efforts to protect sensitive resources as the partner demonstrates reliability (Ink pen \& Tsang, 2005).

Mutual adaptation is an important outcome of the social exchange that takes place in enduring inter-firm ties (Mukherji \& Francis, 2008). As two or more firms simultaneously affect and are affected by each other in relatively enduring ways that make the ties among them get 
stronger, an adaptive process occurs in which products and processes are re-designed to meet the needs of the partners (Mukherji \& Francis, 2008). Social capital is then based on multi-faceted linkages between mutually adapting firms in which the constituent dimensions that make up social capital might interact in potentially complex. This leads to:

Proposition 1a: Social capital can be built in a non-linear, non-uniform manner.

Proposition 1b: Strong and weak inter-firm ties can exhibit different social capital properties even within the same supply network.

Mutual adaptation however can create a kind of convergence through which firms might miss future market-level opportunities that emerge outside the bundle of relationships held by the collaborating firms (Ink pen \& Tsang, 2005). The process of convergence can also lead network ties to become redundant, and an increase in the number of ties can have this same effect if previously strong ties are diluted to pursue new opportunities (McFadyen \& Cannella, 2004). Ties may need to be sacrificed to renew the network's value-creating potential.

The investment in network ties over time shapes social capital, and any move to sacrifice linkages might undermine the body of social capital held by the firm. However, the mix of ties held by a firm may decrease the effect. For example, managers in firms facing rapidly changing conditions are typically compelled to maintain short-term relationships because of concerns about the flexibility of the network (Ryu et al., 2007). Accordingly, a small number of strong ties that are important to the steady supply of key components can be compensated by a large number of weak ties that can be rapidly changed without much expense to social capital or value creation (Noke et al., 2008). 
Still, if trust is undermined or the intensity of the relationship weakens, social capital could rapidly dilute and could be impossible to restore. If such a tie was sacrificed—for example as the firm moves towards a new technology opportunity—-then the firm may lose its ability to rely on that partner in the future. Conversely, low reliance makes a linkage easier to change than a high-involvement one, and so would not appear important in social capital terms. But weak ties can be used as bridges to firms that may be of considerable strategic relevance later, and the consequences of sacrificing these ties is therefore not as obvious or straightforward (Burt, 1992). Sacrificing either type of tie might cause unforeseen problems, particularly where rapid technological change creates uncertainty about which ties might become critical in the future. A resolution to this problem may appear in shared cooperative norms in the cognitive dimension of social capital (Nahapiet \& Ghoshal, 1998). Cooperative norms reflect expectations that two exchange parties have about working together (Cannon \& Perreault, 1999). These norms consist of the shared understanding of what is expected as appropriate behavior, the nature and duration of cooperation, and common expectations of the standards of product-service outcomes (Cannon \& Perreault, 1999). While these norms may appear in formal contracts, they often simply evolve informally through episodes of cooperation (Gulati et al., 2000). Common norms and expectations within a set of relationships might offset problems when discontinuing ties, thereby sustaining value creation in the short-to-medium term. This leads to:

Proposition 2: Clearly defined norms and shared expectations can minimize negative effects to social capital when inter-firm ties are severed.

\section{METHODS}


The case study focuses on Domino Printing Sciences, a UK-based provider of industrial printing technology. A case study was used because this method can provide a more complete portrayal than quantitative approaches (Jick, 1979), and is more appropriate to examine a relationship-based phenomenon such as social capital. Moreover, Yin (1994) specifies that case studies are the preferred strategy when "how" or "why" questions are asked, and when the focus is on a contemporary phenomenon within a real-life context. Single case designs also enable investigators to probe deeply and analyze intensively a phenomenon in its natural setting (Burns, 2000). Thus, a single case can represent a significant contribution to theory building and assist in refocusing the direction of future investigations by revealing whether additional factors not originally included in theory are present (Burns, 2000; Eisenhardt, 1989).

A single case design can make it difficult to generate results that can be generalized broadly (Eisenhardt, 1989). However, Yin (1994) defends the single case approach where the case represents an extreme situation that is sufficiently different from the norm or where a phenomenon has received insufficient conceptual and empirical development. Such powerful opportunities to learn render that single case worthy of documentation and analysis. Meredith (1998) argues that some management phenomena involve highly unique organizations and situations that may not readily lend themselves to broader types of analysis. Domino Printing's experiences during the timeframe discussed here are a strong candidate for a single case methodology because technological upheavals that are truly radical in character do not happen very often in most industries.

Tushman \& Anderson (1986) explain that radical technological disruptions are so fundamentally different from previously dominant technologies that the skills and knowledge required to operate the core technology shift. Such changes in skills and competencies inevitably 
cause major changes in the relationships across firms. The relative uniqueness of Domino's situation during this period in the industrial printing sector's history makes this evidence a valuable contribution to the social capital literature. Specifically, the "non-linearity" of Domino's business environment throughout this period of flux highlights how social capital can be built, re-directed, and consolidated in highly non-linear ways.

The data for this case study was collected via an initial two-hour roundtable discussion and nine semi-structured one-on-one interviews involving senior-level managers at Domino Printing Sciences’ headquarters in Cambridge, England, between April 2002 and August 2003. This timeframe is insightful because the company had recently launched a radical innovation that undermined its existing core products and competencies. Both the old product (industrial inkjet printing) and the new product (industrial laser printing) were dependent on two very different sets of relationships, and this period in the company's history therefore offers powerful insight into the shaping, use, and re-shaping of social capital.

Each discussion was loosely guided by a list of questions, but frequent departures from this agenda were made in the interest of exploring new and interesting points raised during each interview. The format of each discussion was then adapted slightly from one discussion to the next. Unconstrained by rigid questions, semi-structured discussions can lead to new and creative insights, and the refinement of existing theory (Andersen \& Christensen, 2005).

Yin (1994) recommends triangulating multiple sources of evidence to minimize the risk of error within a case study. Accordingly, the case study consists of perspectives from five senior managers within Domino: the CEO, Group Technology Director, Engineering Director, Manufacturing Director, and Purchasing Manager. The five managers were interviewed separately for a period of 1-2 hours each approximately three months after the initial roundtable 
discussion. Following the multiple contact model proposed by Gephart (2004), four of the managers were then re-approached for a second series of one-hour follow-up interviews. This three-phase methodology yielded conclusions that are broadly in agreement and reproducible (Yin, 1994). Observations and conclusions were documented and shared with the participants to ensure that the case study accurately reflected their opinions of the events that led to the development of Domino Printing Sciences’ laser printing innovation.

The case study evidence was analyzed iteratively by clustering and organizing the data around key words drawn from the theory of social capital to discover patterns (Yin, 1994). This approach made it possible to identify and make sense of the social capital activities of Domino and its managers (Faria \& Wensley, 2002), and to explore the interaction between the evidence and existing theory (Strauss \& Corbin, 1990). This analysis is presented in Table 1.

Insert Table 1 about here.

\section{CASE STUDY: DOMINO PRINTING SCIENCES}

\subsection{Company Description and Industry Context}

Based in Cambridge, England, and founded in 1978, Domino Printing Sciences manufactures and distributes industrial inkjet and laser printing systems, employs over 1,700 people, generates annual revenue of over $\$ 200$ million, and controls about 25 percent of the market (Mitchell, 2002). Both Domino and its competitors develop technologically complex capital equipment that is then installed in other firms' manufacturing operations. The nature of this market represents a barrier for new technologies because the adoption of an innovation involves many firms and demands significant investment. 
Domino’s inkjet printers were successful for many years, but feedback from its clients indicated increasing dissatisfaction with the technology's dependence on solvents. Domino's directors identified laser printing as an attractive solution to this concern. But the change from inkjet printing to laser technology required major changes within the company's supply network and a significant shift in Domino's core competencies and internal know-how.

\subsection{The Old Technology: Inkjet Printing}

In Domino’s inkjet system, ink is forced under pressure through a small nozzle before ultrasonic pressure waves cause this fine jet to break up into small droplets. An electrostatic charge determines the trajectory of each droplet. The droplets land in a column on the surface being printed, forming a simple two-dimensional image. Each inkjet unit consists of several modular subsystems that are put together at the customer's site.

\subsection{Buyer-Supplier Relationships for Inkjet Printers}

Domino's core competencies and competitive advantages are rooted in the unique features of its printing systems, and Domino's managers are very protective of the company's intellectual property. Domino's engineering team does all of the detailed design work for the subsystems underpinning the inkjet units, and then forwards the specifications to the company's top-tier suppliers. The subsystems are then manufactured by the suppliers and delivered to Domino as finished units (Mitchell, 2003).

The strong emphasis on intellectual property within the company is reflected in its focus on R\&D. While a considerable fraction of Domino’s R\&D occurs in-house, a significant amount is carried out jointly with external collaborators such as suppliers and universities. These 
arrangements heighten the company's awareness of external developments. These ties do not result in research staff being relocated to or from Domino's facilities; instead, researchers from both parties collaborate via a series of short visits to each other's research centers. These relationships tend to be open-ended, and have lasted from a few months to as long as four years.

A consequence of Domino's decision to purchase completed modular subsystems is that its principal suppliers are highly skilled. Any attempt to shift production to a new top-tier supplier could result in Domino incurring quality validation and training costs of several hundred thousand dollars. Domino’s managers consequently retain suppliers as long as possible and forge ties with suppliers who are large and financially stable enough to weather short-term downturns and market crises, avoiding relationships with firms for which Domino would represent more than 30 percent of the supplier's total revenues.

Nonetheless, the company's managers are prepared to sever these links if a supplier is not working hard to reduce costs and improve its product and process technologies. Domino's managers apply a "meet and compete" policy: to remain in the supply network, firms must meet Domino's ambitious expectations for improvement and remain competitive with other firms in the market. As stated by a senior manager, "We will always give our suppliers a chance to change, but we won’t be constrained if they can't” (Bradley, 2003).

Because inkjet printing technology is well-established, several firms in the market can provide most of the "semi-commoditized" components that go into an inkjet system. Domino's managers purchase these strategically unimportant items from a single supplier so as to leverage cost advantages. Should one of these suppliers become incapable of fulfilling obligations, Domino's managers can quickly and easily make alternative arrangements. But notable exceptions to this outsourcing approach exist. The inks and solvents are tailored for the 
company's own printers. Domino makes substantial profit on these items and manufactures them internally as a result.

\subsection{The New Technology: Laser Printing}

Domino’s move towards laser technology required considerable resources and major changes in its supply network because of the company's lack of core competencies and knowhow in this area. Depending on the material being printed on, a laser beam vaporizes, visibly changes, or reacts chemically with the surface material. This technology is far removed from inkjet printing but involves no consumable chemicals, results in virtually no environmental problems, and has virtually no downtime. Domino manufactures two different laser printers: a dot matrix system capable of printing simple two-dimensional images only; and a scribing laser system based on a single, continuous laser beam to generate a high-quality image. Both systems consist of several modular subsystems that are manufactured separately and put together.

\subsection{Buyer-Supplier Relationships for Laser Printers}

Despite having no in-house skill set to readily develop laser printing systems, Domino’s directors realized the need to move quickly towards this technology: "The technology was evolving so quickly that we were convinced that we would be left out in the cold for subsequent generations of the technology if we didn’t get on board right away” (Mitchell, 2003).

To instantly close this competency gap, Domino acquired Directed Energy, a Californian company that already had a successful laser printing system for sale but did not have Domino’s industry presence. Domino’s strategy depended not on Directed Energy’s existing products but its personnel. The long-term motive for the acquisition was to develop a strong internal expertise 
in laser printing technologies. Domino's managers were instructed to retain the key technical and scientific personnel of Directed Energy after the acquisition. Their efforts were successful. Domino later acquired other firms with highly focused expertise in laser printing technologies such as Sator Laser, based in Germany, specializing in laser scribing systems. Again, Domino has worked diligently to protect its investment in Sator's intellectual property by "ensuring that we keep the ‘miracle guys’ on Domino’s side” (Mitchell, 2003).

Domino's traditional supply base was entirely unable to provide the skills and equipment required to manufacture laser printing systems. But owing to its acquisition strategy, Domino inherited the supply chains and social capital of the firms that it purchased. In doing so however, Domino experienced considerable duplication and overlap in its supply base. Some components were made by several different suppliers using several different designs, distributed throughout the US and Europe. Domino’s managers rationalized the supply chain by using Domino's internal R\&D competencies to design components that could be used across Domino's printer range. A standardized design would then allow Domino to procure larger volumes of similar components from a smaller number of top-tier suppliers. Aggressive consolidation followed: whereas Domino's laser printing division previously relied on 170 suppliers, by 2003 the firm bought all of the necessary subsystems and inputs from only 40 firms (Bradley, 2003).

Domino's managers also recognize that consolidation can go too far. Laser printing is a far less mature technology than inkjet printing, and fewer companies in the marketplace can supply its inputs. Failed suppliers—and the social capital that disappears with them—are not easily replaced. To minimize vulnerability, the company buys some of the more critical subsystems and components from multiple suppliers, and holds weekly phone conferences with them to address any problems before they grow in impact. 


\section{DISCUSSION AND IMPLICATIONS}

\subsection{Testing Proposition 1a}

Three types of relationships underpin Domino’s inkjet technologies: R\&D ties, ties with key component makers (e.g., for modular subsystems), and weaker ties with firms that supply semi-commoditized components. The density and configuration of these ties vary according to the nature of each relationship. In its R\&D ties, Domino's relationships tend to be open-ended, lasting between a few months (strong interaction) to several years (weak interaction punctuated by episodes of increased contact). However, for key component ties, the intensity of interaction is consistently high and long term because of the importance of these inputs to Domino's end products.

This evidence is inconsistent with the path-dependent view espoused in the literature, and therefore helps to usefully extend our understanding of how social capital is formed. Prior investigations in this area portray the creation of social capital as a linear process whereby social capital grows uniformly as the intensity of ties increases (Nahapiet \& Ghoshal, 1998). However, the case demonstrates that, in the long term, ties can experience episodes of strong-weak interaction that are arguably as valuable as strong ties on their own. These interactions can result in a highly non-uniform accumulation of social capital. Even when two types of ties are ostensibly strong—such as Domino’s key component relationships and some of its R\&D tiesthe frequency of cooperation changes depending on the returns the company intends and their relevance to immediate short-term performance (component ties) versus mid-to-long-term performance (R\&D ties). 
The development of social capital therefore does not follow the kind of neatly divided strong-weak dichotomy suggested in the literature; instead, the process by which social capital is shaped is punctuated in time and investment by the firm according to the desired returns and the speed with which these returns are delivered. This evidence supports Proposition 1a. Research into social capital in the buyer-supplier literature should therefore account for the properties of each tie in forming an understanding of how and in what way social capital enables value creation from the buyer-supplier relationships held by a firm. A linear view of social capital overlooks the multidimensional nature of buyer-supplier ties and how these ties can iterate between episodes of strong-weak interaction. Scholars and managers should take care not to misinterpret the social capital value or the business value of a tie.

\subsection{Testing Proposition 1b}

Domino's managers use multiple suppliers for strategically important items, but use only a handful of suppliers for more commoditized items. From a relational dependence viewpoint, the highly-skilled nature of Domino's top-tier suppliers dictates that any attempt to move away from these ties would create considerable costs. This dependence increases the risk of overreliance. Yet a common feature across Domino's relationships is a willingness to sacrifice ties without regard for their strategic importance if the supplier is unable to reduce costs and improve its product and process technologies. A "meet and compete” policy creates a governance mechanism based on expectations and standards. Thus, despite periods of acute relational dependence, the cognitive component of social capital appears to moderate the willingness to sacrifice ties. The relationship might differ with respect to lower-tier suppliers only because the costs of failing to fulfill obligations are less dramatic. 
This evidence suggests that strong and weak ties are guided by different social capital properties even within the same supply network, thereby supporting Proposition 1 b. Ink pen \& Tsang (2005) theorize that social capital works differently across different networks, but the evidence presented here suggests that social capital operates differently within the same network according to the properties of the inter-firm linkage. R\&D ties in particular appear not to agree with what is currently predicted in the literature. $\mathrm{R} \& \mathrm{D}$ ties exhibit a combination of social capital properties associated with either strong or weak ties that oscillate in frequency, duration, and return vis-à-vis what would be expected in more traditional inter-firm linkages. The ways in which a tie is used and the manner in which its importance oscillates in time appear to depend on the value and urgency of the tie's intended return. A static diagnosis of a firm's buyer-supplier relationships will fail to detect the dynamic characteristics of a tie, leading scholars and managers to oversimplify how a tie is built and how the social capital underpinning it is maintained. Tracing the development of ties and mapping how they provide value will prevent scholars from misjudging how ties are formed and maintained, and will prevent managers from making incorrect decisions on the substance of ties.

A framework to interpret these effects is presented in Figure 1.

Insert Figure 1 about here.

\subsection{Testing Proposition 2}

Radical departures from existing technologies can mean that a company cannot draw on its existing network ties or deploy its existing social capital to develop a market presence in this new area. This illustrates a weakness of social capital as an asset: it is tied to existing relationships such that social capital is only powerful within the locus of relationships for which 
it was formed. However, although Inkpen \& Tsang (2005) theorize that social capital could blind firms to opportunities outside its core product technology, the threat did not materialize in this instance even though Domino's existing ties were attached completely to a single product technology. The mix of ties that Domino had with various organizations (e.g., R\&D ties), its relationships with end users, and its persistent use of customer feedback seem to have prevented this kind of blindness. R\&D ties and customer feedback heighten firms' awareness of external developments to prevent blindness to new opportunities, despite the potential cost to social capital and existing product-services. Managers should maintain a diverse mix of strong and weak ties to ensure that the intellectual capital generated from social capital ties fuels their awareness of market concerns and new technology opportunities. Scholars should consider how different bundles of ties mitigate opportunity blindness.

Domino's existing social capital could not be used for leverage en route to pursuing the new laser technology because the company would have had to build new relationships with firms offering know-how in this technology area. Social capital takes time to develop and to become potent enough to begin a meaningful process of exchange. The urgency to grasp this new technology and quickly enter the market with a viable offering meant that it was futile for Domino's managers to begin to slowly develop social capital in this new direction on its own. Domino adopted an acquisition strategy instead.

Previous studies into strategic networks and social capital are largely predicated on the belief that no single firm holds all the resources it needs to compete effectively in dynamic markets (Gulati et al., 2000). But these assumptions do not preclude an acquisition strategy as an alternative or as an addition to relationship building, yet the social capital literature discounts the role of acquisition in profiting from relationships. Acquisition allows the firm to rapidly absorb 
the social capital, networks, and supply chains of those it acquires, thereby overcoming its own limitations. Social capital is therefore important to consider when acquiring target firms, as obtaining the networks of these firms can enable the leveraging of new technologies. However, this strategy produces several unintended consequences that are insufficiently explored in social capital research.

First, the successful integration and deployment of the technology is dependent on retaining the key employees of the acquired firms. An organization's social capital is therefore intertwined with its human capital. The success of Domino's strategy depended on the key scientists, engineers, and employees behind the technology, as these people would have orchestrated supply links and R\&D relationships. Also, this evidence points to the interaction of internal and external social capital. Internal social capital must be built to retain new personnel before consolidating external social capital in newly-acquired buyer-supplier networks. The set of network ties that are obtained through acquisitions are meaningless without the core set of employees who formed them. This evidence extends earlier work by Hitt \& Ireland (2002) which recommends that business leaders must effectively balance human and social capital.

Second, by inheriting the supply chains and social capital of the acquired firms, Domino experienced considerable redundancy across the resulting network because the amount of duplication and overlap among ties increased after each acquisition. In re-shaping its network and social capital, a company must understand which suppliers to retain and which ones to let go to ensure that the company's current and long-term goals are met. The speed of technology development in an industry can generate serious consequences if the abandoned firms go on to develop the next phase of technology. Using internal R\&D competencies to develop a standardized set of components is one way to reduce the number of ties. Sacrifices to social 
capital can then be made by consolidating ties around the firm's strategic needs. This approach allows the firm to strengthen and deepen the most suitable long-term ties while weakening or even eliminating those with companies that will not be able to meet expectations. No undue harm should befall the firm's body of social capital so long as the process is clearly communicated to all relevant stakeholders and not executed abruptly. This evidence offers a useful extension to social capital theory from the buyer-supplier perspective.

The evidence also reveals that attempts to consolidate network ties have limits. When fewer firms in the marketplace have the skills, resources, and expertise required to supply particular inputs, failed suppliers cannot be easily replaced. Using multiple suppliers can help minimize a company's vulnerability, but this approach can force a degree of redundancy in the network. To further minimize risk, Domino intensified the interaction among the firms in its network by instituting weekly phone conferences with the remaining collaborators to repair any relationship-related damage caused by the introduction of the new technology, and to address any problems before they became cumbersome. Thus, to minimize the erosion of social capital during periods when a firm might have to sacrifice some of its network ties, more time, resources, and attention than normal must be dedicated to relationship management with collaborating companies. A firm can further protect its social capital under these circumstances by clearly defining norms and shared expectations with other firms in the network, and by maintaining a high degree of transparency and openness with stakeholders.

This evidence supports Proposition 2 but also extends theory to show that successfully managing social capital over time depends on managing not only expectations and norms but human capital, competitive strategy, redundancy-to-risk ratios, and perceptions of relationship longevity (see Figure 2). 
Insert Figure 2 about here.

\subsection{Theoretical Contributions}

The findings from this study indicate that social capital does not develop linearly as portrayed in prior investigations in this area, but is instead formed through a series of complex interactions among the three dimensions of social capital. The nature of the return offered by the tie and the underlying nature of the tie itself affect how collaborators shape strong and weak ties within their network. These factors condition the frequency of interaction and punctuate the ways in which ties grow over time.

This paper also adds constructively to the debate on the specificity of social capital. Whereas Ink pen \& Tsang (2005) theorize that social capital works differently across different networks, the evidence presented here suggests that the situation is perhaps even more complicated and case-specific than that: social capital can operate differently within the same network according to the properties of the inter-firm linkage.

The Domino case study also serves as a useful real-world reminder that the social capital literature is most constructively considered in addition to other explanatory constructs rather than instead of them. Putnam $(1995,2000)$ assumes that minimizing disconnections between actors is superior to any other strategy to improve organizations, but the evidence presented here strongly hints that social capital can and does work in conjunction with other contributing factors such as a competitive strategy. Such a strategy can take many forms, including a need for partners to meet strict expectations, a preference to shed unproductive ties despite the risks of doing so, or a decision to acquire an outside firm to tap into its existing social capital. 


\subsection{Practical Implications}

The decision to acquire firms to secure their internal know-how might conveniently reduce the amount of time necessary for building social capital and enabling its benefits, but this paper usefully highlights how this shortcut also carries a potential downside in the form of network redundancies. While some of the social capital that resides within an acquired firm would almost certainly be new, the would-be acquiring firm is always faced with the risk that much of the social capital that it is thinking of buying is neither new nor particularly useful. This redundancy represents a cost that is frustratingly difficult to quantify.

The Domino example does offer useful practical insight into how the loss of social capital can be minimized when a firm is consolidating or severing its network ties. Managers can reduce the damage to the firm’s existing social capital by investing more time, resources, and attention than normal in the area of relationship management with collaborators. The Domino team emerged from this transitional period with a rejuvenated and highly functional network by clearly defining norms and shared expectations with other network firms throughout this period of extreme change, and by maintaining a high degree of transparency and openness with Domino’s collaborators.

\subsection{Limitations and Future Research}

Although the case study contains multiple events and perspectives, all of the data were gleaned from employees of Domino Printing. The events described here may have looked differently to Domino’s network partners. Future studies in this area would benefit from capturing these multiple perspectives. Another shortcoming of the methodology is that it focuses on a single company in a single industry. While a single case study approach adds richly to the 
understanding of the phenomena being observed, it detracts from the ability to generalize the results broadly. Subsequent investigations in this area should consider whether social capital plays a similar role in inter-firm ties in other sectors. This case study provides an interesting exception to the blanket generalizations about social capital offered by Ink pen \& Tsang (2005) and Putnam (1995, 2000), but it does not explain how social capital is developed and maintained in every situation. This specific example might differ from others.

Future research in this area should empirically analyze if and how different strategies for forming and shaping social capital yield different outcomes. Prior studies largely assume that shedding social capital weakens performance, but the evidence presented here suggests that shedding ties can be a strategic necessity that reinforces long-term performance in certain situations. It therefore follows that understanding how firms manage the structural, relational, and cognitive dimensions of social capital under these very different circumstances is important towards understanding how social capital contributes to long-term value creation.

\section{ACKNOWLEDGMENTS}

The authors thank JBR Editor Arch Woodside, JBR Associate Editor Tony Ellson, and two anonymous reviewers for their comments on earlier versions of this manuscript. All errors are the responsibility of the authors. 


\section{REFERENCES}

Andersen PH, Christensen PR. Bridges over troubled water: Suppliers as connective nodes in global supply networks. Journal of Business Research 2005; 58: 1261-1273.

Bensaou M. Portfolios of buyer-supplier relationships. Sloan Management Review 1999; Summer: 35-44.

Bradley, Simon. Personal interview with the authors, 16 July 2003. Mr. Bradley was the CEO of Domino’s laser printing division.

Burns RB. Introduction to Research Methods. London: Sage Publications, 2000.

Burt RS. Structural Holes: The Social Structure of Competition. Cambridge, MA: Harvard University Press, 1992.

Cannon J, Perreault WD. Buyer-seller relationships in business markets. Journal of Marketing Research 1999; 36 (4): 439-460.

Cousins PD, Lawson B. Sourcing strategy, supplier relationships and firm performance: An empirical investigation of UK organizations. British Journal of Management 2007; 18: 123-137.

Eisenhardt KM. Building theories from case study research. Academy of Management Review 1989; 14 (4): 532-550.

Faria A, Wensley R. In search of 'interfirm management' in supply chains: Recognizing contradictions of language and power by listening. Journal of Business Research 2002; 55: 603-610.

Gephart, R. From the Editors: Qualitative Research and the Academy of Management Journal. Academy of Management Journal 2004; 47 (4): 454-462. 
Gulati R, Nohria N, Zaheer A. Strategic networks. Strategic Management Journal 2000; 21: 203215.

Hitt MA, Ireland RD. The essence of strategic leadership: Managing human and social capital. Journal of Leadership and Organization Studies 2002; 9 (1): 3-14.

Hughes M, Ireland RD, Morgan RE. Stimulating dynamic value: Social capital and business incubation as a pathway to competitive success. Long Range Planning 2007; 40 (2): 154177.

Inkpen AC, Tsang EWK. Social capital, networks, and knowledge transfer. Academy of Management Review 2005; 30: 146-165.

Jick TD. Mixing qualitative and quantitative methods: Triangulation in action. Administrative Science Quarterly 1979; 24 (4): 602-611.

McFadyen MA, Cannella A. Social capital and knowledge creation: Diminishing returns of the number and strength of exchange relationships. Academy of Management Journal 2004; 47: 735-746.

Meredith J. Building operations management theory through case and field research. Journal of Operations Management 1998; 16 (4): 441-454.

Mitchell, Rick. Personal interview with the authors, 18 April 2002. Dr. Mitchell (retired) was Domino Printing’s Group Technology Director.

Mitchell, Rick. Personal interview with the authors, 13 July 2003.

Morris MH, Holman JL. Source loyalty in organizational markets: A dyadic perspective. Journal of Business Research 1988; 16 (2): 117-131.

Mukherji A, Francis JD. Mutual adaptation in buyer-supplier relationships. Journal of Business Research 2008; 61 (2): 154-161. 
Nahapiet J, Ghoshal S. Social capital, intellectual capital, and the organizational advantage. Academy of Management Review 1998; 23: 242-266.

Noke H, Perrons RK, Hughes M. Strategic dalliances as an enabler for discontinuous innovation in slow clockspeed industries: Evidence from the oil and gas industry. R\&D Management 2008; 38 (2): 129-139.

Putnam RD. Bowling alone: America’s declining social capital. Journal of Democracy 1995; 6 (1): 65-78.

Putnam RD. Bowling Alone: The Collapse and Revival of American Community. New York: Simon \& Schuster, 2000.

Rodan S, Galunic C. More than network structure: How knowledge heterogeneity influences managerial performance and innovativeness. Strategic Management Journal 2004; 25 : $541-562$.

Ryu S, Park JE, Min S. Factors of determining long-term orientation in interfirm relationships. Journal of Business Research 2007; 60 (12): 1225-1233.

Strauss A, Corbin J. Basics of Qualitative Research: Grounded Theory Procedures and Techniques. Thousand Oaks, CA: Sage Publications, 1990.

Tushman ML, Anderson P. Technological discontinuities and organizational environments. Administrative Science Quarterly 1986; 31 (3): 439-465.

Yin RK. Case Study Research: Design and Methods. Thousand Oaks, CA: Sage Publications, 1994. 
Figure 1. Shaping and Using Social Capital in Different Types of Ties

\begin{tabular}{|c|c|c|}
\hline \multicolumn{3}{|c|}{ Structure of ties } \\
\hline Strong tie(s) & Combination/Hybrid & Weak tie(s) \\
\hline Key components & $R \& D$ & $\begin{array}{l}\text { Semi-commoditized } \\
\text { components }\end{array}$ \\
\hline $\begin{array}{l}\text { - Intense, repeated } \\
\text { interaction }\end{array}$ & $\begin{array}{l}\text { - Oscillating episodes of } \\
\text { intensity/interaction }\end{array}$ & $\begin{array}{l}\text { - Low intensity ties with } \\
\text { minimal interaction }\end{array}$ \\
\hline $\begin{array}{l}\text { - Immediate and } \\
\text { significant return }\end{array}$ & $\begin{array}{l}\text { - Short and long-term return } \\
\text { based on duration and } \\
\text { objectives }\end{array}$ & $\begin{array}{l}\text { - Immediate but non- } \\
\text { significant return }\end{array}$ \\
\hline - Several partners & - Several partners & - Few partners \\
\hline $\begin{array}{l}\text { - Common when product } \\
\text { complexity high }\end{array}$ & $\begin{array}{l}\text { - Irrelevant of complexity; } \\
\text { driven by future opportunities }\end{array}$ & $\begin{array}{l}\text { - Support complex } \\
\text { products; common when } \\
\text { product complexity low }\end{array}$ \\
\hline $\begin{array}{l}\text { - High reliance; high } \\
\text { replacement cost }\end{array}$ & $\begin{array}{l}\text { - Opportunity-based; future } \\
\text { orientation overrides sense of }\end{array}$ & $\begin{array}{l}\text { - Low reliance; low } \\
\text { replacement cost }\end{array}$ \\
\hline 4 & reliance & \\
\hline \multicolumn{3}{|c|}{ Overlapping feature: Common cooperative norms and shared expectations } \\
\hline \multirow[t]{2}{*}{ mitigates } & & \\
\hline & $\downarrow$ & moderates \\
\hline High & Relational dependence & Low \\
\hline Low & Willingness to sacrifice & High \\
\hline
\end{tabular}


Figure 2. Re-shaping and Consolidating Social Capital over Time

\begin{tabular}{|c|c|c|c|}
\hline \multicolumn{3}{|l|}{ Current Technology } & \multirow[t]{2}{*}{ New Technology } \\
\hline \multicolumn{3}{|c|}{$\begin{array}{l}\text { Value of existing } \\
\text { social capital }\end{array}$} & \\
\hline Extensive & \multicolumn{2}{|c|}{$\begin{array}{l}\text { Ability to deploy } \\
\text { social capital }\end{array}$} & Minimal \\
\hline $\begin{array}{l}\text { Build } \\
\text { (creates tailored ties) }\end{array}$ & \multicolumn{2}{|c|}{$\begin{array}{l}\text { Strategic } \\
\text { option }\end{array}$} & $\begin{array}{r}\text { Acquire } \\
\text { (risk of redundancy) }\end{array}$ \\
\hline \multicolumn{4}{|c|}{ Consolidating network through new ties and sacrificing old ties requires } \\
\hline $\begin{array}{l}\text { Human capital } \\
\text { dependence in } \\
\text { shaping new ties, } \\
\text { revising old ones, } \\
\text { and capturing value } \\
\text { from acquired ones }\end{array}$ & $\begin{array}{l}\text { Common design } \\
\text { platform and } \\
\text { shared expectations } \\
\text { to mitigate } \\
\text { negativity }\end{array}$ & $\begin{array}{l}\text { Maintain some } \\
\text { redundancy to } \\
\text { minimize risk and } \\
\text { offer future options }\end{array}$ & $\begin{array}{l}\text { Invest time, effort, } \\
\text { and resources to } \\
\text { reinforce value and } \\
\text { endurance of ties }\end{array}$ \\
\hline
\end{tabular}


Table 1. Analysis of Case Data

\begin{tabular}{|c|c|c|c|}
\hline Key term & Evidence & Interpretation and analysis & Associated with \\
\hline Urgency (1) & $\begin{array}{l}\text { Dissatisfaction with existing technology } \\
\text { (harmful chemicals, reliability, recurring } \\
\text { expenses). }\end{array}$ & Risk losing customers to alternative technologies. & $\begin{array}{l}\text { Urgency (2); } \\
\text { applicability of } \\
\text { existing social capital. }\end{array}$ \\
\hline $\begin{array}{l}\text { Relevance of } \\
\text { technological } \\
\text { competencies }\end{array}$ & $\begin{array}{l}\text { Fundamental differences in science and } \\
\text { technology of inkjet and laser printing; current } \\
\text { supply base and internal competencies locked } \\
\text { into core technology. }\end{array}$ & $\begin{array}{l}\text { Application of existing social capital compromised } \\
\text { by insufficient core competencies and know-how; } \\
\text { urgency negates relationship-building as entry } \\
\text { strategy. }\end{array}$ & $\begin{array}{l}\text { Urgency }(1,2) ; \\
\text { applicability of } \\
\text { existing social capital; } \\
\text { acquisition strategy. }\end{array}$ \\
\hline $\begin{array}{l}\text { R\&D ties (mix } \\
\text { strong/weak) }\end{array}$ & $\begin{array}{l}\text { Heavy focus on R\&D and IP protection; } \\
\text { heightens exposure to external developments; } \\
\text { simultaneous strong and weak ties; last few } \\
\text { months to several years. }\end{array}$ & $\begin{array}{l}\text { Strength of ties varies by time horizon and return; } \\
\text { some ties show episodes of strong interaction but } \\
\text { limited interaction otherwise; mitigates blindness } \\
\text { associated with social capital. }\end{array}$ & $\begin{array}{l}\text { Blindness; structural } \\
\text { component. }\end{array}$ \\
\hline Strong ties & $\begin{array}{l}\text { Outsources subsystem manufacture (both } \\
\text { technologies); specialist components demand } \\
\text { strong ties to protect IP investment. }\end{array}$ & Specialist suppliers create dependence. & $\begin{array}{l}\text { Relational } \\
\text { dependence. }\end{array}$ \\
\hline $\begin{array}{l}\text { Relational } \\
\text { dependence }\end{array}$ & $\begin{array}{l}\text { Shift to new top-tier suppliers carries significant } \\
\text { costs; retain suppliers as long as possible; } \\
\text { norms/expectations mitigate risk. }\end{array}$ & $\begin{array}{l}\text { Strong ties exhibit significant dependence due to } \\
\text { specialist competencies and know-how; willingness } \\
\text { and ability to sacrifice heavily compromised but for } \\
\text { norms/expectations. }\end{array}$ & Cooperative norms. \\
\hline $\begin{array}{l}\text { Cooperative } \\
\text { norms }\end{array}$ & $\begin{array}{l}\text { Prepared to sever links if supplier is not } \\
\text { reducing costs and improving product and } \\
\text { process technologies; “meet and compete” } \\
\text { policy sets expectations. }\end{array}$ & $\begin{array}{l}\text { Moderates willingness to sacrifice despite severe } \\
\text { relational dependence. }\end{array}$ & $\begin{array}{l}\text { Relational } \\
\text { dependence. }\end{array}$ \\
\hline Weak ties & $\begin{array}{l}\text { Suppliers of semi-commoditized components; } \\
\text { switching costs minimal and effect small. }\end{array}$ & $\begin{array}{l}\text { Strategic unimportance leads to few or single } \\
\text { suppliers; cost advantages. }\end{array}$ & Cooperative norms. \\
\hline Urgency (2) & $\begin{array}{l}\text { Laser technology evolving quickly; risk missing } \\
\text { out on subsequent generations. }\end{array}$ & $\begin{array}{l}\text { Time and resource constraints limit ability to } \\
\text { develop new relationships and social capital; } \\
\text { alternative entry strategy needed. }\end{array}$ & $\begin{array}{l}\text { Product complexity; } \\
\text { relevance of current } \\
\text { competencies; }\end{array}$ \\
\hline
\end{tabular}




\begin{tabular}{|l|l|l|l|}
\hline & & & $\begin{array}{l}\text { applicability of } \\
\text { existing social capital. }\end{array}$ \\
\hline $\begin{array}{l}\text { Applicability } \\
\text { of existing } \\
\text { social capital }\end{array}$ & $\begin{array}{l}\text { Social capital tied to relationships for which it } \\
\text { was formed. }\end{array}$ & $\begin{array}{l}\text { New technology obsoletes existing ties; } \\
\text { incompatibility. }\end{array}$ & Acquisition strategy. \\
\hline $\begin{array}{l}\text { Acquisition } \\
\text { strategy }\end{array}$ & $\begin{array}{l}\text { Immediate acquisition of technology, supply } \\
\text { chains, and social capital; investment protected } \\
\text { by retaining "miracle guys". }\end{array}$ & $\begin{array}{l}\text { Multiple acquisitions create redundancy; need for } \\
\text { consolidation; dependent on human capital. }\end{array}$ & $\begin{array}{l}\text { Consolidation; human } \\
\text { capital. }\end{array}$ \\
\hline Human capital & $\begin{array}{l}\text { Supply chains and social capital of acquired } \\
\text { firms dependent on human capital. }\end{array}$ & $\begin{array}{l}\text { Key scientists and engineers formed supply links; } \\
\text { ability to leverage social capital depends on } \\
\text { retaining human capital. }\end{array}$ & $\begin{array}{l}\text { Acquisition strategy; } \\
\text { consolidation. }\end{array}$ \\
\hline Consolidation & $\begin{array}{l}\text { Redundancy in final network due to } \\
\text { acquisitions; risk/vulnerability created by } \\
\text { uncertainty over future technological } \\
\text { developments. }\end{array}$ & $\begin{array}{l}\text { consolidate ties; degree of redundancy retained to } \\
\text { mitigate risk. }\end{array}$ & Acquisition strategy. \\
\hline
\end{tabular}

